\title{
Annemarie Schwarzenbach'ın Winter in Vorderasien - Tagebuch einer Reise Başlıklı Seyahat Günlüğünde Türkiye Tasviri
}

\author{
Melda Keser (D), Tekirdağ
}

doi) https://dx.doi.org/10.37583/diyalog.759425

$\ddot{O} z$

İsviçreli gazeteci, foto muhabiri, yazar, fotoğrafçı Annemarie Schwarzenbach, gazetecilik göreviyle Ekim 1933'te, Irak’ta sonlanacak doğu yolculuğuna çıkmıştır. Seyahatinin iki ayını Türkiye'de geçirmiştir. Gördüklerini, edindiği izlenimler çerçevesinde kaleme alarak, 1935 yılında Winter in VorderasienTagebuch einer Reise başlığıyla yayınlatmıştır. Seyahat, Türkiye'de reform çalışmalarına ve Cumhuriyet'in onuncu yılına denk gelmektedir. Ancak aktarımlarına bakıldığında, eleştirel bakış açısı dikkat çekmektedir. Yürütülecek bu çalışma ile Schwarzenbach'ın Alman edebiyatına sunduğu Türkiye imgesinin anlaşılmasına katkı sağlanması amaçlanmıştır. Bu nedenle, seyahatname Türkiye'ye dair tasvirleri çerçevesinde ele alınacaktır.

Anahtar Sözcükler: Annemarie Schwarzenbach, Seyahatname, Isviçre Edebiyatı, Cumhuriyet Reformları Türkiye imgesi

\section{Abstract \\ Annemarie Schwarzenbachs descriptions of Turkey in her travel book'Winter in Vorderasien- Tagebuch einer Reise'}

Annemarie Schwarzenbach was a Swiss journalist, reporter, author and photographer who embarked on a mission as a journalist to the Orient in October 1933. This journey took her until Iraq. She spent the first two months of her journey in Turkey and wrote about her observations in Turkey. Her travel book was published in 1935 under the title Winter in Vorderasien-Tagebuch einer Reise. Her journey coincided with the reform process in Turkey and the tenth year of the founding of the Turkish Republic. However, when her writings are scrutinized, critical perspective stands out. This study aims to contribute to the understanding of the Turkish image, which Schwarzenbach represents in German literature. For this reason, her descriptions of Turkey will be discussed in this analysis.

Keywords: Annemarie Schwarzenbach, travel book, Swiss literature, republican reforms, Turkey image 


\section{EXTENDED ABSTRACT}

A travel book is a text including important and valuable details to be mentioned by a writer. Those can be chosen in parallel with the aim of travel as well as observed details in the moment. The Swiss journalist, photographer and writer Annemarie Schwarzenbach's travel diary titled as Winter in Vorderasien- Tagebuch einer Reise represents an important example in this topic in German literature.

She wrote her travel book as a diary presenting her own arguments about Turks and Turkey. Her work is an important example of travel books about the East, especially as a literary text about Turkey in German Literature, discussing the reformation period of the newly founded Turkish Republic. The book depicts the image of the young republic in 1933 based on her criticism. This study aims to analyse the understanding of the Turkish image represented by Schwarzenbach in German literature.

Annemarie (Mina Renéé) Schwarzenbach was born on the $23^{\text {rd }}$ of May, 1908 in Switzerland and died at the age of 34 . She came from a bourgeois background. Her father is one of the most important industrialists, a silk producer in Switzerland. Schwarzenbach studied in Zurich and Paris and earned in 1931 her doctorate while she was 23. Her first novel Freunde um Bernhard was published in the same year in Vienna. Schwarzenbach was an extraordinary successful young women despite to her young age. She was a close friend of Erika and Klaus Mann siblings. It is a general argument that her political perspective was influenced by the Mann siblings as well her choices in the life. Schwarzenbach was one of the founders of the exile journal Sammlung and she also financed it. She lived in Berlin until mid-1933 in Mann siblings circle. In 1933, she had to move to Switzerland from Berlin due to national socialist executions and pressure. In the same year, she began to work as a photo journalist and became popular. She travelled to Scandinavia, Russia, Near East and often to America.

In October 1933, she was appointed as a journalist to travel across the East starting from Istanbul where she spent two months, and ending in Iraq. Her travel book was published in 1935 titled as Winter in Vorderasien- Tagebuch einer Reise (translated as Winter in West Asia- Diary in English). Although it was written in the diary format, only dates of arrival and departure were given in the book, rather than day to day entries, suggesting her occasional writing attitude.

Although we also see some detailed dialogs in her book as seen in the conversation with the manager of railway J. Bey in Kayseri, which led to criticise the Turkish officers and the reforms of Turkish Republic. This article attempts to demonstrate her approach to criticize Turkey by considering the similar expressions.

Schwarzenbach visited in Turkey on this journey Istanbul (October 15-26 ${ }^{\text {th }}$ ), Ankara (October $26^{\text {th }}$ ), Kayseri (November 1933) and Konya (December 3-7 $7^{\text {th }}$ ). In Ankara, she made a trip to the shrine of Hüseyin Gazi. In addition to the chapters devoted to each city, she wrote a separate chapter named as Ritt auf den Hussein Ghasi Ankara, 20. November 1933. In this chapter, she explains effects of the Ataturk's reforms in some practises of the religion and public life, for instance banning the sects and closing the dervish lodges. She claims that people damaged the shrine of Huseyin Gazi and hurt his soul due to this new reform based on her opinion. 
Furthermore, Schwarzenbach criticizes the position of the immigrant GermanJewish professors in Turkey in a similar negative perspective as seen in the case of Turkish Republic reforms. She implies very often this professor's performance. Such this passage she highlights that she takes pride in their works. Besides, she often refers this professors situation and their future in Turkey worrisome. This article analyses the chapters Istanbul, Ankara, Ritt auf den Hussein Ghasi Ankara and Kayseri and concluded that Schwarzenbach draws highly negative image of Turkey and Turks. 


\section{Giriş}

Seyahatnameler, seyyahın önemli ve aktarmaya değer gördüğü ayrıntılardan oluşmuş metinlerdir. $\mathrm{Bu}$ ayrıntılar, seyahatin amacı doğrultusunda seçilmiş olabileceği gibi, seyyahın gördüğünde kayda değer bulmasıyla seyahatnameye dâhil edilmiş ayrıntılar da olabilmektedir. İsviçreli gazeteci, foto muhabiri, yazar ve fotoğrafçı Annemarie Schwarzenbach'ın Winter in Vorderasien- Tagebuch einer Reise başlıklı seyahat günlüğü bu konuda Alman Edebiyatı alanında yazılmış önemli bir örnektir. Schwarzenbach, Türkiye'ye 1933 yılının Ekim ayında gazetecilik göreviyle gitmiştir. Seyahat notlarını günlük biçiminde yapılandırmıştır. Bununla beraber, günlügüun içeriğini oluşturan Türkiye ve Türkler hakkındaki bilgileri öznel bir bakış açısıyla aktarmış ve gördüklerini tasvir ederken, kişisel bilgi ve yorumunu öne çıkarmıştır.

Seyahatinin iki ay kadar zamanını geçirdiği Türkiye'de İstanbul, Ankara, Konya ve Kayseri'de kalmıştır. Buralarda gördüklerini, edindiği izlenimler ve kişisel yorumları çerçevesinde kaleme almıştır. Seyahatinin tamamına dair yazılarını 1935 yılında Winter in Vorderasien- Tagebuch einer Reise başlığıyla yayınlatmıştır. İsviçre Edebiyatında seyahatname türüne dâhil olan bu eserindeki Türkiye bölümleri, Alman okuyucuya sunduğu Türkiye imgesi açısından oldukça önemlidir.

Ancak, Schwarzenbach ve eserleri üzerine yürütülmüş çalışmalarda, seyahat yazıları arasında öncelikli olarak İran, Afganistan, Afrika ve Amerika seyahatleri ilgi görürken, Türkiye seyahat günlüğü daha çok Schwarzenbach hakkındaki biyografi çalışmalarında veya eserlerinin biçim ve yazım özellikleri konusundaki çalışmalarda değinilmiş bir metindir.

Petra Heinrichs'in 2010 yılında yayınlanan "Unser Leben gleicht einer Reise ": Türkei-Bilder in den Texten Annemarie Schwarzenbachs başlıklı çalışması, Türkiye seyahat notlarını ele almaktadır. Ancak, odaklandığı konu Schwarzenbach'ın feminist yaklaşımı ve doğu ile batıyı cinsiyet kimlikleri üzerinden yorumlamasıdır. Schwarzenbach'ın doğuya ve batıya atfettiği cinsel kimlikleri, bu bağlamdaki algısını ve yorumlarını işlemektedir. Heinrichs'in bu çalışması, Schwarzenbach'ın Türkiye seyahat günlüğü konusunda şimdiye dek yürütülmüş tek çalışma olarak görünmektedir.

Schwarzenbach ve eserleri konusunda yürütülmüş çalışmalar, 1990'lı yılların başında yazarın feminist çevrelerce gündeme getirilmesiyle canlanmış, sonrasında ise 100. yaş günü olan 2008 yılına kadar geri planda kalmıştır. 2008 yılı itibariyle ise özellikle biyografi çalışmaları çoğunlukta olmak üzere, yaşadığı kişisel sorunların ve çöküşün eserlerindeki iz düşümleri, foto muhabirliği, edebi eserlerinde biçim ve anlatım özellikleri çerçevesinde ele alınan bir yazar olmuştur.

Schwarzenbach, Türkiye seyahatini, cumhuriyetin ilk yılları ve Almanların Türkiye'ye göçünün yoğun olduğu dönemde gerçekleştirmiştir. Ancak seyahat günlüğüne bakıldığında, aktarımlarında eleştirel bakış açısının öne çıktığı görülmektedir. $\mathrm{Bu}$ bağlamda yürütülecek çalışmada, öncelikle yazar hakkında biyografik bilgi verildikten sonra, sırasıyla Türkiye seyahati, seyahat günlüğünde Türkiye bölümünün biçim ve yazın özellikleri ele alınacak, ardından seyahat günlügünde Türkiye ve Türkler konusundaki tanımları, tasvirleri ve ifadeleri incelenecektir. Yürütülecek bu çalışma ile Schwarzenbach'ın Alman edebiyatına sunduğu Türkiye imgesinin ortaya konmas1; böylece öncelikle 20. yüzyıl Alman 
Edebiyatında Türk ve Türkiye imgesi konusunda yürütülecek çalışmalara olmak üzere, Cumhuriyet Tarihi, sosyoloji ve sosyal bilimlerin Alman Dili ve Edebiyatı dışındaki çeşitli disiplinlerine de katkı sağlanması amaçlanmıştır.

\section{Annemarie Schwarzenbach}

Annemarie (Mina Renéé) Schwarzenbach, 23 Mayıs 1908 tarihinde İsviçre'de dünyaya gelmiş, 34 yaşında vefat etmiştir. Babası ipek üreticisi olarak İsviçre'nin zengin sanayicilerindendir. Dönemin yüksek burjuva standartlarında yetiştirdikleri kızları Annemarie, 1927 yılı itibariyle Zürih ve Paris’te yükseköğrenimine devam etmiş, 1931 yılında, henüz 23 yaşındayken tarih alanında doktora eğitimini tamamlamıştır.

Schwarzenbach, kısa yaşamını birçok konuda uçlarda yaşamış, aynı zamanda birçok başarıyı da döneminin şartlarında bir kadın olarak yaşamına sığdırmıştır. 1931 yılında, doktora tezini vermesinin yanı sira, Freunde um Bernhard adlı ilk romanı Viyana'da yayınlanmıştır. Erika ve Klaus Mann kardeşler ile yakın arkadaşlığının etkisiyle yazdığı bir roman olduğu görüşü yaygındır. Mann kardeşler, Schwarzenbach'ın yakın arkadaşıdır. Edebi çalışmalarında, politik görüş ve eylemlerinde, hatta yaşadığı yerlerin seçiminde bile bu iki kardeşin etkisinin yoğun olduğu aktarılmaktadır. Schwarzenbach'ın uyuşturucu alışkanlığı da 1932 yılında, bu arkadaşlıkları aracılığıyla girdiği çevrede başlamıştır (Linsmayer 2011: 672). Schwarzenbach, birçok kez klinikte tedavi görmesine rağmen, bağımlılıktan kurtulamamıştır.

1933 yılında, foto muhabirlik yapmaya başlamış ve bununla ün kazanmıştır. İsviçre'nin çeşitli gazeteleri için bu röportajları yürütme göreviyle İskandinavya, Rusya, Yakın Doğu, birçok kez de Amerika'ya seyahat etmiştir. 1935 yılında, İran'da görevli Fransız diplomat Claude Clarac ile evlenmiş ve bir süre İran'da kalmıştır (a.g.m. 2011: 672). 1939 yılında Afganistan'a gerçekleştirdiği seyahatten döndükten sonra kısa süre İsviçre'de kalmış, ardından Amerika'ya göç etmiştir. Bu göçün nedeni olarak, kendini Alman sürgün edebiyatına dâhil görmesi gösterilmektedir. Öte yandan Schwarzenbach, Klaus Mann'ın Sammlung adlı sürgün edebiyatı dergisinin sponsoru ve kurucularından biridir. Amerika'da Emergency Rescue Committee ile çalışmış ve çeşitli Amerikan gazeteleri için makale yazarlığı yapmıştır (a.g.m 2011: 673).

1940 yılında arkadaşı Margot von Opel ile yaşadığı bir sorun sonucunda Conneticut'ta özel bir kliniğe yatırılmıştır. Buradaki intihar girişiminden sonra ise New York'ta bulunan ve kullandığı yöntemlerle ünlü olan Bellevue Hastanesine nakledilmiştir. Bu hastaneden çıkabilmesi, kardeşi Alfred Schwarzenbach'ın girişimleri ve Annemarie Schwarzenbach'ın Amerika'dan ayrılacağını taahhüt etmesiyle mümkün olmuştur. Ailesiyle sürekli sorunlar yaşayan Schwarzenbach, bu dönüşünden sonra da iyi karşılanmamıştır. Bunun üzerine, Nisan 1941 'de, İsviçre gazeteleri için çalışmak üzere İspanya ve Portekiz üzerinden Kongo'ya gitmiştir. Tetuan'da eşini de ziyaret ettikten sonra, sıtma hastalığından bitkin düşmüş halde Temmuz 1942'de İsviçre'ye dönmüştür. Aynı yıl Eylül ayında, yeni görevi için Portekiz seyahatine çıkmasına kısa bir süre kala, Engadin'de bisikletiyle kaza geçirmiş ve başından yaralanmıştır (a.g.m. 
2011: 673). Çeşitli ve zorlu tedavi denemelerinden ${ }^{1}$ oluşan bir süreçten sonra $15 \mathrm{Kas}$ mm 1942 tarihinde vefat etmiştir.

Schwarzenbach, henüz genç yaşına rağmen edebiyatçı, gazeteci ve foto muhabiri olarak ünlenmiştir. Uzun süreli seyahatleri, gazeteciliğinin yanı sıra edebi eserlerini de kaleme aldığı süreçler olmuştur. Birlikte yolculuk ettiği kişiler çoğunlukla, kendisi gibi gazeteci veya yazar kadınlardır. Ella Maillart, Barbara Hamilton ve fotoğrafçı Marianne Breslauer bunlardan bazılarıdır (Heinrichs 2010: 114-115). Dönemin siyasi şartları da göz önünde bulundurulduğunda, Schwarzenbach'ın ve birlikte seyahat ettiği kadınların, çağlarına göre sıra dişı kişilikler olduğu anlaşılmaktadır.

Çevresinin standartlarına uymadığı ve bununla ilgili ailesiyle de sürekli çatışma halinde olduğu, Schwarzenbach'ın bilinen en genel özelliklerinden biridir. Nitekim Schwarzenbach'ın annesi, kızının ölümünden sonra, kendince onun itibarını korumak amacıyla, geride kalan yazılarının ve çalışmalarının büyük bir kısmını yok etmiştir. Fakat yakın bir arkadaşı 5000 adet negatifi kurtarmış ve saklamıştır. Ancak, Schwarzenbach, ölümünden sonra unutulmuştur (Huszar 2009: 8). 1987 y1lında hakkında yeni çalışmalar yapılmaya başlanmasıyla ise tekrar hatırlanmıştır. Bu tarihten itibaren, Schwarzenbach'1 veya eserlerini konu eden çalışmalar hız kesmeden artmış (Obermüller 2008: 1), 1990'lı yılların başlarında; özellikle feminist sanatçılar arasında kült bir kişilik halini almıştır. Doğumunun 100. yılında dört adet biyografísi yayınlanmıştır (Huszar 2009: 8). Aynı yıl, 2008'de Schwarzenbach, edebiyat tarihi kaynaklarında İsviçre edebiyat tarihi yazarları arasına dâhil edilmiştir (Schmidt 2011: 604).

2005 y1lı itibariyle, Schwarzenbach'ın daha önce yayınlanmamış bazı eserleri de basılmıştır. Ufer/In Tetouan başlığı altında toplamış olduğu şiirleri (2005), Die vierzig Säulen der Erinnerung başlıklı hikâye derlemesi (2008) Fransızca-Almanca; Land der Heimkehr başlıklı İran seyahatnamesi (2008) ise Farsça-Almanca olmak üzere iki dilli olarak basılmış eserleri bunlardan bazılarıdır. Das glückliche Tal adlı eseri ise 1987 yılındaki basımından sonra ilk kez yeniden yayınlanmıştır. 2008 yılında, 100. doğum günü özel basımlarında Lyrische Novelle, Bei diesem Regen, Tod in Persien, Winter in Vorderasien, Insel Europa adlı eserleri yeniden ele alınmıştır (Schmidt 2011: 604). 2007 yılında da, yazarın tarih alanındaki Beiträge zur Geschichte des Oberengadins başlıklı doktora tezi ve kaleme almış olduğu Lorenz Saladin biyografisi yayınlanmıştır (a.g.m 2011: 605). Aynı yıllarda hakkında yürütülen çalışmalarda öne çıkan diğer bir konu da fotoğraf röportajlarıdır. 2008-2010 yıllarında Schwarzenbach'1 bu çerçevede ele alan çalışmalar da yayınlanmıştır (a.g.m. 2011: 607).

\section{Türkiye'ye Seyahati}

Sınırları kabullenmeyen kişiliğiyle tanınan Schwarzenbach (Obermüller 2008: 3) bu özelliği ile ilişkili olarak seyahat tutkusuyla da ünlenmiştir. Seyahatin, Schwarzenbach için bir nevi yaşam şekli olduğu söylenebilir. İlk bakışta işi sebebiyle veya merak ettiği yerlere gidiyor gibi görünse de seyahatin, içinde yaşadığı dünyanın sınırları dışına çıkmak bağlamında önem taşıdığı dikkat çekmektedir.

\footnotetext{
${ }^{1}$ Ayrıntılı bilgi için bkz.: Linsmayer, 2011.
} 
Schwarzenbach, 1931 yılında doktorasını tamamladıktan sonra, ailesinden uzakta ve arkadaşları Erika ile Klaus Mann'ın yakınında olacağı Berlin'e taşınmıştır. Fakat nasyonal sosyalistlerin güç kazanmasıyla beraber, Schwarzenbach da Berlin'den ayrılmak zorunda kalmıştır. Arkadaşı Marianne Breslauer'den etkilenip fotoğrafçılığı gazeteciliği ile birleştirerek, kendine yeni bir yol açmıştır. Schwarzenbach 1933 baharında foto muhabirlik göreviyle, Breslauer ile birlikte İspanya ve Andorra'ya gitmiştir. Buralarda yürüttüğü gazetecilik çalışmalarının İsviçre'de foto muhabirliği öne çıkaran Die Zürcher Illustrierte adlı dergide yayınlamasıyla, bu dergide çalışma süreci de başlamıştır. Aynı yıl Ekim ayında İran'a gitmek üzere yola çıkmış ve ilk Türkiye seyahatini gerçekleştirmiş, bu yolculuktaki röportajlarını aynı dergide yayınlamıştır (Dieterle 1992: 67). Haberlerini yayınlayan tek yayın organı bu dergi değildir. İsviçre'nin çeşitli gazete ve dergilerinde Schwarzenbach'ın röportajları ve haber metinleri yer almıştır. Neue Zürcher Zeitung da bunlardan biridir. Türkiye seyahatini aktardığı Winter im Vorderasien başlıklı seyahat günlüğ̈ şeklindeki çalışmasının yanı sıra, seyahati boyunca kaleme aldığı çeşitli haber yazıları da adı geçen yayın organlarında yayınlanmıştır².

Schwarzenbach, trenle gerçekleştirdiği yolculuğunda 15 Ekim 1933 tarihinde İstanbul'a varmıştır. İstanbul'da 10 gün kadar kalıp, Ankara'ya geçmiştir. Ankara'dan sonra sirasıyla Kayseri ve Konya’ya seyahat etmiştir. Türkiye yolculuğunda en uzun süre kaldığı yer 1 aya yakın bir süreyle, Ankara'dır. Kaldığı illerde at binmesi dışında, şehirlerde kendisine şoför ile tahsis edilmiş otomobilleri, şehirler arası yolculuklarında ise gece trenlerini kullanmıştır. Yolculuğunda yalnız değildir, fakat yol arkadaşları konusunda bilgi vermemektedir.

\section{Winter in Vorderasien - Tagebuch einer Reise içinde Türkiye Günlüğü}

Annemarie Schwarzenbach, 15-26 Ekim 1933 tarihlerinde İstanbul, sonrasında sirasiyla Ankara (26 Ekim 1933), Kayseri (Kasım 1933) ve Konya'da (3 - 7 Aralık 1933) bulunmuş, 8 Aralık’ta Halep'e varmıştır. Türkiye'ye dair gözlem ve izlenimlerini, bulunduğu şehrin başlığı altında aktarmaktadır. Fakat Ankara'da görmeye gittiği Hüseyin Gazi Türbesi (20 Kasım 1933) için ayrı bir başlık açmıştır. Günlük, Bağdat seyahatinden aktarımlarıyla sonlanmaktadır. Yazdıklarını, 1935 yılında Winter in Vorderasien- Tagebuch einer Reise başlı̆̆ıyla kendisi yayınlatmıştır.

Schwarzenbach, seyahatini günlük biçiminde aktarmışsa da, kronolojinin daha çok seyahatin güzergâhı; şehirlere varış veya şehirlerden ayrılış zamanları çerçevesinde verildiği görülmektedir. Şehirlerde gördükleri, yaptıkları vb. hakkındaki bilgilerin tamamı böylece tek tarih altında toplanmıştır. Örneğin, 10 gün kaldığı İstanbul'u, “İstanbul” başlığ 1 altında "15 Oktober 1933" tarihini vererek anlatmıştır. Bir sonraki tarih “Ankara” başlığı için verdiği 26. Ekim 1933’tür. Ankara günlüğünde ikinci tarih, yeni başlık vererek ayrı olarak anlattığ 1 Hüseyin Gazi Türbesi ziyareti içindir. Aynı biçim özelliğini Kayseri notlarında da korumuşken, Konya bölümünde Konya'dan

\footnotetext{
${ }^{2}$ Söz konusu haberlerden biri, Türkiye'deki üniversite reformu hakkında Neue Zürcher Zeitung gazetesinde "Die Reorganisation der Universität von Stambul" başlığıyla 3 Aralık 1933 tarihinde yayınlanan yazısıdır.
} 
ayrılışını günün tarihini vererek anlatmıştır. Her bir tarih, altında belirtildiği şehre ilişkin ortalama 2-8 sayfa arasında seyahat notu içermektedir.

Metin türünün yazar tarafından "günlük" olarak adlandırılmasına karşın, metnin bahsi geçen şekilde yapılandırılmış olması, yazım stili ve metin incelendiğinde anlaşılır olabilmektedir. Schwarzenbach, metni sadece ilgisini çeken ve anlatmaya değer bulduğu resimleri sıralayan bir üslupta kaleme almıştır. Örneğin, Istanbul'a dair aktarımı, şehrin manzarası ve Aya Sofya'nın kendisi üzerindeki etkisini dile getirdiği "ve işte Stambul'du, Aya Sofya'nın kubbesiyle (bir çocukluk hayali resmi), 1şıl 1şıl sahilleri, gemiler, yelkenlileri, beyaz evlerle dolu denizi, açık mavi bir pusla çevrili, berraklıktan yansıyan..." (a.g.e. 2002: 2) cümlesiyle başlamaktadır. Hemen ardından, şehrin sokaklarında, kalabalıkta kaybolma isteğine ilişkin düşüncesini kısaca dile getirmiş, İstanbul'un coğrafi konumu nedeniyle tarihteki etkisini ifade ettiği ve her cümleyi tek paragraf olarak kullandığı kısa anlatımlarla devam etmiştir. İstanbul'da çeşitli yerleri gezdiğini, çeşit çeşit insan gördüğünü söyleyerek bunu "[...] renkli Doğu'yu, o hiç-bir-zaman-tam-keşfedilemeyecek-olan” (a.g.e. 2002: 3) olarak tanımlamış, ardından, Beyazıt camii bahçesinde fotoğrafını çektiği yaşı bir adamı, fotoğrafladığı halini tarif ederek metne devam etmiştir. Adamın yüz ifadesini yorumlarken ise, Türklerin tarihte yorumlanma şeklini ifade etmiş, ardından "Im grossen Basar" (büyük Pazar) dediği, muhtemelen Kapalıçarşı olan yerin sakin olduğunu, satıcıların ısrarcı olmadığını yazmıştır (Schwarzenbach 2002: 3). Günlügün tamamında, bu şekilde kısa aktarımlarla, art arda farklı konu veya durumlardan söz ettiği görülmektedir. Bunlar arasında güne dair bir kronoloji olmadığı gibi, yaşanan, görülen şeylerin sıralaması da bilinmemektedir.

Schwarzenbach'ın, seyahati kim veya kimlerle gerçekleştirdiği konusunda metinde hiçbir bilgi yer almamaktadır. Ayrıca, Türkiye'deki üniversite reformuna ilişskin İstanbul Üniversitesi çerçevesinde, İsviçre'nin Neue Zürcher Zeitung adlı gazetesinde 3 Aralı 1933 tarihinde Die Reorganisation der Universität von Stambul (Stambul'daki üniversitenin yeniden yapılandırılması) başlıklı haberi yayınlanmasına rağmen, İstanbul'da veya Ankara'da görüştüğü hiç kimseye dair bilgi vermemiş, görüşme veya inceleme yaptığından dahi bahsetmemiştir. Oysa arşivindeki Türkiye fotoğraflarında, Ankara'da Almanların inşa etmekte olduğu binaları ziyaret ettiği görülmektedir ${ }^{3}$. Yolculuğu sırasında tesadüfen karşılaştığı, tanıştı̆̆ yabancılar hakkında ise bilgi aktarmaktadır. Örneğin, Konya'dan ayrılırken, gece treni için yaptıkları ara yolculukta, Musul'a gitmekte olan bir Çek mühendisle tanıştığından ve onun anlattığı konulardan bahsetmektedir (a.g.e. 2002: 24). Türkiye'den ayrılırken trende tanıştığ1, Israil'e gitmeye çalışan Yahudi genci ve onun anlattıklarını, aralarındaki sohbeti de aktarmaktadır (a.g.e. 2002: 26-28). Bu aktarımlar, metnin bütününe bakıldığında, Schwarzenbach için, durum ve diyalog fotoğraflaması izlenimi vermektedir. Elbette bu kişilerin metinde yer alma nedeni, Schwarzenbach'ın onları yer vermeye değer bulmasıdır. Fakat bu, yolda ilginç bulduğu manzaraları, görüntüleri fotoğraflamasından

\footnotetext{
${ }^{3}$ Söz konusu fotoğraf arşivi erişim linki:

https://commons.wikimedia.org/wiki/Category:Photographs_by_Annemarie_Schwarzenbach_-

_Turkey?uselang=de\#/media/File:CH-NB_-_T\%C3\%BCrkei,_Ankara-_Bauten_-

_Annemarie_Schwarzenbach_-_SLA-Schwarzenbach-A-5-02-130.jpg (son erişim:30.04.2020).
} 
farksızdır. Sadece olanı, olduğu gibi sunmaktadır. Buna bir örnek de, İstanbul'da camileri gezdiklerini söyledikten sonra, bu geziye dair aktardıkları arasında iki cümleden oluşan bir paragrafla, öncesi ve sonrasında konuya ilişkin hiçbir yorumda bulunmadan, bir kesit olarak verdiği bilgidir 'Bir Türk bana eski, el yazması bir Kuran'1 gösterdi. "Kutsal kitabı yazmaya ancak düşüncelerden uzaklaş1labildiği sürece devam edilebilir. Düşünceler insanı meşgul etmeye başladığı zaman durmak gerekir." (a.g.e. 2002:5).

Schwarzenbach'ın, yanındaki kişilerden bahsetmeme kuralı, kendisine refakat eden Türkler konusunda bozulmaktadır. Kişilerin isimlerini vermese de, bir baş harfle ve yaptığı işi belirterek bilgi vermektedir. Örneğin, Kayseri'de kendisini, birlikte olduğu kişi veya kişilerle tren istasyonunda karşıllayan kişiden bahsederken "J. Bey, bu bölgedeki demiryolunun müdürü” (a.g.e. 2002: 16) şeklinde tanıtmıştır.

Günlüğüne dair diğer önemli bir özellik, gördüğü veya bahsi geçen yerlerin tarihlerine mutlaka değinmesi ve şehirlerin eski isimlerini en az bir kere kullanmasıdır. İstanbul "Stambul", Ankara "Angora", Kayseri "Caesarea", metinde bahsi geçen Bursa "Brussa" ve İzmir "Smyrna" olarak kullanılmıştır. İstanbul, başlık haricinde metnin tamamında Stambul olarak geçmektedir.

\section{Türkiye ve Türklere İlişkin Tasvirleri Istanbul}

Schwarzenbach, İstanbul günlüğünde, camileri ve çeşitli çarşıları, pazarları gezdiğini söyledikten sonra, Beyazıt Camii bahçesinde gördüğü ve fotoğrafladığını aktardı̆̆ 1 bir adamı tarif etmektedir (a.g.e. 2002: 3). Kıyafetinden başlayarak tasvir ettiği adam, dünyanın en önemli işini yaparmışçasına parasını almak ve pazarlık etmek için elini uzatmışken, yüzünde bilge bir ifadeyle bakışlarını onlara yöneltmiştir, fakat deneyimlerinden kaynaklı bir olgunlukla bakmaktadır ve bu bakış kesinlikle alaycı değildir. Schwarzenbach, yaşlı kadınların da çoğu zaman, tarif ettiği bu ifadeye sahip olduğunu söyledikten sonra, "- insan o zaman anımsıyor, Türklerin baskın bir millet olduğunu, işlerini Levantenlere, Yunanlara, hatta Mısırlılara yaptırdığını” (a.g.e. 2002: 3) şeklinde bu anlatımını tamamlamaktadır. Sokakta gözlemlediği adamın ifadesi konusunda yorumu olumsuz değildir. Fakat kişideki özelliği, Türklerin, tarihte yönetme anlayışından kaynaklı bir durum olarak yorumlaması dikkat çekicidir. Türklerin, birbirinden farklı milletleri bir arada yönettiği şeklinde bir ifadeden ziyade, diğer milletleri boyunduruğu altına alan bir millet olarak görmekte ve okuyucuya bu bakış açısını sunmaktadır. Türkler için "baskın millet” tanımını kullanması, bu bakış açısını vurgulamaktadır. Oysa, deneyim, bilgelik çerçevesinde yorumlamaya devam etmiş olsayd1, içinde olumlu veya olumsuz yorum içermeyen "Tarihte birçok milletten topluluğu yönetmiş bir millet" veya buna denk, nesnel bir cümle kullanması gerekirdi. Bu bağlamda, Schwarzenbach'ın Türkleri yönetim biçimi üzerinden bu cümleyle tasviri, olumsuz bir yorum izlenimi uyandırmaktadır. 


\section{Ankara}

Ankara günlüğünde, şehir merkezi dışında gördüğü yerlerin çoraklığından bahsederken, o dönem inşa edilmekte olan Çubuk Barajı'ndan söz ettiği anlaşılmaktadır. Schwarzenbach, Ankara çevresinin, sadece bazen damar gibi bir akarsuyun görülebileceği kadar çorak olduğunu, şehrin daha da dışında kocaman bir baraj yapıldığını, inşaatının sağlamlığını da vurgulayarak, inşaatın hızla yükseldiğini aktarmaktadır. Baraja ilişkin yorumu ise, içini dolduracak suyun henüz bulunamadığı, duvarın, yolunu şaşırmış bir dev olarak beklemede olduğu şeklindedir (a.g.e 2002: 6). Barajın adını vermese de, inşaatın 1933 yılında Ankara'da, Türkiye'nin ilk barajı olarak bilinen Çubuk Barajı inşaatı olduğu açıktır. İfade şekli ise, inşası üç yıl kadar sürecek ve o dönem henüz yeni inşa edilmeye başlanmış bir baraj için, yanlış yürütülmüş bir proje izlenimini uyandıran türdedir. O tarihte, çorak bir bölgeye hızla, ileriye yönelik gerçekleştirilen böylesi önemli bir projeyi, neredeyse alenen "hatalı" olarak tanımlayarak aktardığı görülmektedir.

Schwarzenbach Ankara seyahatinde, Cumhuriyet'in onuncu yıl kutlamalarına denk gelmiştir. 26 Ekim'de vardığı Ankara'da gördüğü hareketliliği ve süsleme çalışmalarını "tüm bunlar genç Türkiye Cumhuriyetinin kuruluş yıldönümü kutlamaları içindi” diyerek aktarmaktadır. Bu kutlamalar için özel bir marş söylendiğini, köylü, öğrenci, asker, kim olduğu fark etmeksizin, herkesin marşı ezbere bildiğini, çevre illerden insanların Gazi’yi bir kez görebilmek umuduyla yollara düşmüş olduğunu, aynı insanların tepesinden geçen uçakların Berlin'den Nadolny’yi, Bükreş’ten Titulescu'yu ve Litwinow'un vekillerini, genç Rusları ve dünyanın dört bir yanından diplomatları Ankara'ya taşıdığını ifade etmektedir. Bu aktarımından sonra, durumu "ve herkes Ankara'nın bu gösterisini izlemeye geliyordu. Bizi temin ettikleri üzere, Türkiye'nin kalbi olacak olan Ankara'nın" şeklinde tasvir etmektedir (a.g.e. 2002: 7). Bu ifadesindeki, kutlamaların büyüklüğünü vurgularken "gösteri" (Schauspiel) kelimesini kullanması tesadüfi görünmemektedir. Ankara'nın Türkiye'nin kalbi olacağına dair söyleminin ardından, ötede hâlâ Selçuklu Kalesi'nin kalıntılarının, eski Angora köyü sokaklarının oluşturduğu öbeğin ve Augustus Tapınağına yaslanan caminin görüldüğünü aktarmaktadır. Kendisini Ankara'nın parlak geleceği konusunda temin edenlere cevap verircesine yaptığı bu hatırlatma dikkat çekicidir. Okuyucuya, orada daha önce kurulmuş ve yıkılmış medeniyetleri hatırlatmaktadır. Şehirlerin önemlerinin geçiciliğini vurgulaması, Ankara'ya dair koyulan hedeflere "boş hayal" düzleminde baktığı izlenimini uyandırmaktadır. Bu bağlamda, Ankara'nın yeni kurulan bir şehir olarak, gelecekte ülkenin kalbi, merkezi olacağının söylenmesini ciddiye almadığı anlaşılmaktadır.

Ankara'nın şehir yapılanması konusundaki anlatımı da, barındırdığ 1 yorumlar çerçevesinde ilginç ayrıntılar içermektedir. Aşağıda enine büyüyen bir şehir olduğunu, asfalt yollarının nereye varacağını bilmeden ilerleyip, tepelere uzanarak gözden kaybolduğunu, geniş bir caddenin kilometrelerce uzanarak hükümet binalarının olduğu yere ulaştığını ve orada heybetiyle "Holzmeister'in İç İşleri Bakanlığı'nın” tüm alana hâkim olduğunu dile getirmektedir (a.g.e. 2002: 8). Nazi rejiminden dolayı Almanya'da çalıştığı üniversiteden ayrılmak zorunda kalan mimar Clemens Holzmeister, günlük içinde, Türkiye'deki göçmen Almanlara dair adını geçirdiği tek kişidir. Holzmeister'in, 
reform döneminde Türkiye'de bulunmuş birçok göçmen gibi, katkısı elbette tartış1lmaz. Fakat Türkiye'nin "yenilik hareketleri”" çerçevesinde "neredeyse hayalperest” olduğunu her firsatta vurgulayan Schwarzenbach, bu yenilikler kapsamında Türkiye'de eser üretmiş olan kişiyi sadece mimar olarak değil, binanın sahibi değerinde sunmaktadır. Bina elbette Holzmeister'in eseridir, ancak bu sadece yaptığı bir iştir. Schwarzenbach'ın metnin devamında Türkiye'de bulunan Avrupalılar konusundaki yorumlarıyla birlikte değerlendirildiğinde, şehrin tasvirinde Holzmeister' in önemini vurgulama çabasında olduğu göze çarpmaktadır. Bu vurgu ise, Holzmeister'in Türklerle iş birliği içinde ortaya koyduğu bir çalışmadaki öneminden ziyade, tek başına taşıdığı bir önemi vurgulama, yüceltme izlenimini vermektedir.

Başkentteki hummalı çalışmayı, fotoğraflarcasına metinde okuyucuya sunmaktadır. İç İşleri Bakanlığı'nın bulunduğu alana kısa süre içinde diğer bakanlık binalarının da yapılacağını, alanın mimari özelliklerini anlatmaktadır. Fakat yine hemen ardından, o dönemki eş zamanlı yoğun ve hızlı çalışmalar için "Tüm bunlar korkunç, anlamsız, anca bir haber filmi kadar etkileyici” diyerek tanımlamaktadır (a.g.e 2002: 8).

Yeni başkentin şehirleşme sürecini "Tüm bunlar Ankara, Gazi'nin taşlaşmış iradesidir" şeklinde ifade ettikten (a.g.e. 2002: 8) sonra, şehre birkaç saat uzaklıktaki bir köyde Cumhuriyet kutlamaları için dinlenmekte olan insanlara dair gözlemlerini aktarmaktadır. Yol boyunca da "kutsal şehre" ulaşmak için yollara düşmüş çeşit çeşit insanların yanından geçtiğini belirttikten (a.g.e. 2002: 9) sonra, insanların yı̆̆ınlar halinde, birlik içinde hareket etmesine, bunun ürkütücülüğüne değinmektedir. $\mathrm{Bu}$ durumu hayali bir hikâye ve bazı benzetmelerle ifade etmektedir. Hikayesinde, tepelerden inen yollar isimsiz şehre doğru uzanırken gittikçe genişliyor, insanları taşıyan hayvanlar hücum edercesine yanlarından geçiyor, gürültü gittikçe yükseliyor ve yankılanarak katlanıyor, bu gidiş hücuma dönüşüyor, doğa hareketleniyor, tepeler kendi etrafında ağır ağır dönmeye başlıyor, susuz dere yatakları dalgalanırcasına hareketleniyor, bitki örtüsü kuruyor, ağaçlar sararıyor ve sessizce yere eğiliyor, bozkırda yerden diller çıkıyor, her şey birbirini su ve ateş gibi yutmaya başlıyor, ta isimsiz şehrin sokaklarına ulaşıyorlar, kaldırım taşlarının boşluklarından yaban otları fişkırıyor, binalar yıkılıyor, toz bulutu duvarlarını yutuyor, insanlar yaşamaya devam ediyor, lokantalarında yemeklerini yemeye devam ediyorlar, tepelerinde kale dikiliyor, Kürtler, türbanlılar, hırsızlar, dilenciler yokuş aşağı geliyor, yarasalar gibi genişliyorlar, ağıtlarını yakıyorlar, öküz arabaları gümbürdüyor, bozkır yeniden şehirde beliriyor, askerler dikilmeye devam ediyor, emre çelik gibi itaat ediyorlar, fırtınanın geldiğini görüyor, nöbet kulübelerinin önünde huzursuzlanıyorlar, fırtına çadırlarını savuruyor, yok olup gitmiş nöbet yerlerinde nöbete devam ediyorlar ve onları serbest bırakacak bildirimi bekliyorlar, hiç gelmeyecek olan bildirimi (a.g.e. 2002: 10).

Ankara'ya gösterilen ilgiyi, atfedilen önemi, kendisine göre askerlerin emre itaatinin anlamsızlığını, kurguladığı hikâyedeki benzetmelerle eleştirmektedir. Eleştirisinde, kitle, yığın ve kontrol adı altında ortaya çıkan kontrolsüzlük olguları dikkat çekmektedir. Bunların altını çizerek, kitle ruhunun tehlikeli olabilecek yıkıcı yanını vurguladığı anlaşılmaktadır. Kurguladığı sahnenin bitiminde "Avrupalılar bu ülkede korkuyor. Hiçbiri burada kendini evinde hissetmeyecek ve yıllar bunu değiştirmeyecek" demektedir (a.g.e. 2002: 10). Schwarzenbach, Almanya'da ortaya 
çıkan kitle hareketi sonucunda mağdur olan tarafa mensuptur. Yahudi değildir, fakat Nazi rejimine muhaliftir. Türkiye'de kendini güvende hissetmediğini söylediği Avrupalıların da Almanya'dan kaçmak zorunda kalınca, Türkiye'de reform çalışmalarında görevlendirilmiş kişiler olduğunu devamındaki "Onlara, yerine getirdikleri, ama başardıklarında memnuniyetlerinin artmadığı çok önemli görevler veriyorlar" şeklindeki ifadesiyle belirtmektedir (a.g.e. 2002: 11).

$\mathrm{Bu}$ kişiler kendi ülkelerinde, kitle hareketinden zarar görmüş, hayatta kalabilmek için ülkelerini terk etmişlerdir. Schwarzenbach'ın kitlesel coşkuyu, kontrolsüz bir çılgınlığa ve sonunda yıkıma dönüşen haliyle resmedip, ardından bu kişilerin kaygısından bahsetmesinin altında, o dönem Türkiye'de gördüğü atmosferi Almanya'dakine benzetmesinin yattığı anlaşılmaktadır. Oysa Türkiye'de amaç, kurumları ve sistemleri dünyanın ileride olan ülkelerinin standardına getirmektir. Kurtuluş savaşında dünya gücü ülkelerinin işgaline karşı ülkece karşı koymuş bir milletin, kurtuluşundan sonra yeni kurulan devlete bağlılık göstermesini ve bilimsel alan dâhil olmak üzere, her alanda standartlarını yükseltecek hedeflere odaklanmasını hayli olumsuz bir bakış açısıyla değerlendirmektedir. Göçmen Almanların ülkede kendini güvende hissetmemelerini dile getirmesinin de aslında kendi gelecekleri konusundaki kaygılarıyla ilişkili olduğu metnin devamında görülmektedir.

Mevcut atmosferden ve gelişmelerden rahatsızlığını sık sık dile getiren Schwarzenbach, günlüğünün devamında, Ankara'da bu yabancılardan birkaç kişinin, sürekli koyun eti ve tavuk yemeye tepki gösterdiğine dair bir anekdot aktarmakta ve anekdotta bahsettiği günden beri Ankara'da da tıpkı Viyana'daki gibi "Schweinebraten" ve "Apfelstrudel" yenebildiğini ifade etmektedir (a.g.e. 2002: 11). İyi evlerde yaşadıklarını, tenis kortları ve kulüplerinin olduğunu, bunların yanı sıra daha birçok şeye sahip olduklarını ve geleceğe inanan, akılcılığın sunduğu nimetlere bağl1, medeniyeti ilerletmeye odaklı bir ülkede yaşadıklarını; Avrupa'da ise bu unsurların geçerli olmadığını ifade etmektedir. Türkiye'yi donanımlı ve ilerici, halkının refahı ve toplumun gelişimini hedefleyen demokratlar tarafından yönetilen bir ülke olarak tanımlamaktadır. Avrupalıları getirten yöneticileri bu özelliklerle tanımlarken, halkın "bu emeğe karşılık vereceğinden kuşku duyulmadığını", ama görevlendirilerek Avrupa'dan getirtilenlere yakın zamanda ihtiyaç kalmayacağının düşündürüldüğünü belirtmektedir. Hiçbirinin, ülkenin başarısından şüphe etmediğini, ama herkesin kendisiyle ilgili şüphe içinde olduğunu bunun da yabancıları korkuttuğunu açıklıkla ifade etmektedir (a.g.e. 2002: 11). Schwarzenbach'ın bu konuda böylesi bir açıklıkla konuşması, söz konusu kişilerden verilen bilgileri aktardığını düşündürmektedir. $\mathrm{Bu}$ bağlamda, Schwarzenbach'ın Ekim 1933'te Türkiye'nin Ankara'da şahit olduğu atmosferini sürekli olumsuz bir bakış açısıyla ele alma nedenlerinden birinin, ülkedeki göçmenlerin kaygısı olduğunu söylemek mümkündür.

\section{Hüseyin Gazi Türbesi}

Schwarzenbach, 20 Kasım 1933 tarihinde Hüseyin Gazi Türbesi’ni görmeye gitmiştir. Anlatımına başlamadan önce, birkaç yıl önce 3 İsviçreli dağcının türbeden dönüş yolunda çobanlar tarafından kovalandığını, hırpalandığını ve tehdit edildiğini anlatmaktadır. Yaşanan bu olayı, yabancıların tekke ziyaretine tepki gösterilmesi olarak 
yorumlamıştır (a.g.e. 2002: 13). Kendi grubunun ise bu seyahatte otuz kişi olduğunu söylemekte, fakat diğer kişilere dair hiçbir bilgi vermemektedir. Türbeden ne şekilde haberdar olduğu veya neden görmek istediği gibi konularda da metinde herhangi bir aktarımı bulunmamaktadır. Yolda, karşılaştıkları kişilere "Hussein Ghasi Tekke?" diyerek yol sorduklarını ve onların el işaretleriyle yol tarif ettiğini aktarmasından (a.g.e. 2002: 14), yanlarında Türkçe konuşan veya çevirmenlik yapan kimsenin olmadığı anlaşılmaktadır.

Schwarzenbach, şehirler veya kasabalarla ilgili kimi zaman tarihi bilgiler vermektedir. Bunun yanı sıra seyahat notlarından, Cumhuriyet'in ilanından sonra getirilmiş kanun ve uygulamalara da hâkim olduğu anlaşılmaktadır. Hüseyin Gazi türbesini tarif ederken, son birkaç aydır kimsenin gelmediği bir yer olarak tanımlamaktadır. Ardından, böyle kutsal kabul edilen yerlerin, gelişmelerden memnun olmayanların, tutucuların, sürülmüş din adamlarının, gericilerin, yeni devlet yönetiminden nefret edenlerin ve onu kutsal dinlerinin düşmanı olarak görenlerin toplanma alanları olmasından korkulduğunu dile getirmektedir. Bu nedenle İstanbul' da dervişlerin tekkelerinin kapatılmış olduğu bilgisini verdikten sonra "hatta rüzgârın dövdüğü bu dağ başında dahi, zavallı çobanlar için kutsal olan mezarı bile parçalama gereği duymuşlar" demektedir (a.g.e. 2002: 15). Tekke ve zaviyelerin kapatılmas1 konusunda verdiği bilgi doğrudur, fakat mezarın parçalanması konusunda aktardığ bilgilerin kaynağını vermemiştir. Buna rağmen kesin bir dille ifade etmektedir. Türbeyi tasvir ettikten sonra, ayrılırken orayı geride bırakmalarını "[...] ardımızda yine gözden kaybolurken incitilmiş kutsal kişinin dağı" şeklinde ifade etmiştir (a.g.e. 20002: 15). O dönem için gerek duyulması üzerine, devlet yönetiminin aldığı kararı eleştirmekte, fakat eleştirisinin altında yatan nedenleri sunmadığ 1 gibi, eleştirisine neden olan bilgileri ve kaynağını da sunmamaktadır.

\section{Kayseri}

Schwarzenbach, Hüseyin Gazi Türbesi hakkındaki anlatımını tamamladıktan sonra, tam tarih vermeden, sadece Kasım 1933 diyerek, Kayseri anlatımına başlamaktadır. Gece yolculuğu ile vardıkları Kayseri'de kendilerini karşılayan ve ilgilenen kişiyi "bu bölgedeki demiryolu hattının müdürü J. Bey” olarak tanıtmaktadır. Bu kişi hakkında ve kendisiyle yaptıkları konuşmaları aktardığı kısımlar dikkat çekicidir.

Müdürü, "yeni hükümete kendini adamaya hazır genç nesilden" şeklinde değerlendirirken olumsuz bakış açısı, cümlenin devamında kullandığı "kendini hayranlıkla, gönüllü olarak devlet dogmasının emrine sunan” şeklindeki tasviriyle kendini göstermektedir. Schwarzenbach'ın, yeni hükümetin toplum ruhundaki yansımasından rahatsız olduğu bir kez daha açıkça görülmektedir. "O ve onun gibilerin sürekli medeniyet kelimesini kullanması, beraberinde yeniliklere dair bitmek bilmeyen gündemleri, yenilikleri, ilerleme telaşları bizim için en az Ankara'daki Cumhuriyet Bayramı kutlamaları gösterisi kadar sarsıcıyken, J. Bey tüm bunlardan büyük bir keyif alıyordu" demesi, kitlesel coşkudan duyduğu rahatsızlığı ortaya koymaktadır. Kendisinin de ifade ettiği üzere, J. Bey'in de savunucularından olduğu hedef, ilerleme, akılcılık ve ilericilik olsa da, bunun ortaya konma şeklinden rahatsızdır. Rahatsızlığının nedenini, Cumhuriyet dönemi yenilik hareketlerini, aynı paragrafta kullandığı "kitle 
çılgınlı̆̆gı" ifadesi ile tanımlayarak ortaya koymaktadır (a.g.e. 2002: 16). Schwarzenbach'ın burada kullandığı Massenwahn (kitle çılgınlığı) kavramının, ilgili literatürde Nazi rejiminin kitle hareketleri bağlamında sıklıkla kullanıldığı bilinmektedir. Bu bağlamda, Schwarzenbach'ın da, Türkiye seyahati öncesinde Nazi uygulamaları nedeniyle Berlin'den ayrılmak zorunda kalmış bir yazar ve gazeteci olarak, Türkiye'deki kitlesel dönüşümü, Almanya'da o dönem ortaya çıkan kitle hareketinin verdiği korku üzerinden değerlendirdiği bir kez daha görülmektedir.

Türkiye'nin yenilik hareketine gönüllü hizmette bulunan biri olarak tanımladığ J. Bey'in, demiryolları müdürü olarak yetersizliğini ortaya koymaya yönelik tanımları da oldukça önemlidir. Schwarzenbach J. Bey’i, elektrik düzeneği ile güzellik kraliçesini, Ankara-Samsun tren hattının kurulması ile Avrupa'dan ucuz avizelerin alımı arasındaki ayrımı bilmeyen biri olarak tanıtmaktadır. Misafiri olarak duydukları rahatsızlığın, kendileriyle J. Bey arasındaki cehalet uçurumundan ziyade, J. Bey'in güveni ile kendilerinin şüphesi arasındaki uçurumdan kaynaklandığını dile getirmektedir (a.g.e. 2002: 16). Anlatımına, J Bey'in, kendilerini otele götürmesi için hizmetçi tahsis ettiğini söyledikten sonra, at arabasıyla gittiklerini, Erciyes Dağı'nı görmek istediğini söyleyerek devam etmektedir.

"Ertesi gün” diyerek başladığı anlatımında yine J Bey’e yer vermektedir. J Bey'in Schwarzenbach'ın gezisi için tahsis ettiği aracın bilgisini “iş görür bir Chevrolet: şehrin en iyisi" şeklinde vermektedir (a.g.e 2002: 17). Devamında, çevrede görülen evler hakkında konuştukları diyaloğu vermesi de yine J. Bey'in ve Türkiye'nin tutumunu ortaya koymaya yönelik görünmektedir. J. Bey'in, o evlerin harabe olmadığını, yerine yenisi yapılmak üzere yıkılan eski evler olduğunu söylemesiyle başlayan diyalog, Schwarzenbach'ın aktarımına göre, insanları sokağa atan, yoksul insanları umursamayan bir anlayışın barbar tutumu karşısında şaşkınlığa uğramalarıyla son bulmuştur:

"Bunlar hazine değil" dedi. "Evler özellikle yıkılıyor, hiçbir işe yaramıyorlar, hepsi yeniden yapılacak."

"Peki ya bu eski evlerde yaşayanlar?" diye sorduk.

"Onlara yeni arsalar sunuluyor ve yapacakları yeni evlerin mimari projesi veriliyor."

"Paraları var mı ki?"

"Çoğu ev yapmak istemiyor” dedi J. Bey, "O zaman da onlar için yapabileceğimiz bir şey yok"

"Öylece ortada mı birakıliyorlar?"

"Fark eden bir şey yok" dedi, "ülkede zaten çok fazla yoksul insan var".

Fransızca konuşuyordu, yani aşırı olan her şeyi hafifleten, bize barbarca geleni bile yine de insan etkileniyordu ve ancak şehirden ayrılınca rahatliyordu, bir zamanlar Kapadokya'nın başkenti olan ve adını Romalı Kayzer'den alan şehirden (a.g.e. 2002: 17).

J Bey'in, kendileriyle yabancı dilde, tercümansız konuşmasını, sadece "Fransızca, aşırılıkları örten bir dil, barbarlığı bile" olarak yorumlamıştır. Oysa Schwarzenbach bu sohbet sırasında "biz" diyerek bahsettiği grubuyla, barbar olarak adlandırdığı insanlar tarafından ağırlanmış, saygı görmüştür. J. Bey’in, Avrupa’nın o dönem en önemli dili olan Fransızcayı akıcı konuşacak donanıma sahip olması ve sohbet edebiliyor olmalarının, İsviçre'den gelmiş bir grup gazeteci ve misafirle bir kurum müdürü olarak 
bizzat kendisinin ilgilenmesinin Schwarzenbach için önemsiz bir detay olduğu izlenimi oluşmaktadır. Diyalogda, bir devlet kurumunun müdürünün ağzından aktardığ bilgilerin doğrulanması maalesef okuyucu için mümkün değildir. Konunun detayına ilişkin bir konuşma, bütünlük veya bilgi bulunmamaktadır metinde. Bir devlet kurumu müdürünün ciddiyetle "İnsanların evlerini yıkıp, onları ortada mı bırakıyorsunuz?" sorusuna "ülkede zaten yoksul insan çok, fark etmez ki" deme ihtimali, okuyucu tarafından sorgulanmaya açık görünmektedir. Ankara hakkındaki notlarını aktarırken, insanların atların üstünde günlerce yolculuk ederek, Cumhuriyet bayramı kutlamaları için Ankara'ya ulaşmaya çalıştığını aktaran bir gazetecinin, başka bir bölümde "halk devlet tarafından sokağa atılıyor" anlamına gelen anlatımının eleştiri odaklı ve tutarsız olduğunu göstermektedir.

Öte yandan, gün gün değil de sonradan aktarılan notlar olduğunu bildiğimiz bir günlükte, olumsuz izlenimi sunacak şekilde, Schwarzenbach'ın sadece aklında kaldığ 1 kadarıyla aktarılmış cümleler olma olasılığı da göz ardı edilmemelidir.

Schwarzenbach'ın, seyahat yazılarını kaleme alırken, notlarından veya aklında kalanlardan metin oluşturduğu bilinmektedir (Schmidt 2011: 607). Öncelikle, gün içinde gördüklerini, edindiği izlenim ve deneyimlerine göre not etmektedir. Kısa günlük yazılarını andıran bu notlarını, daha sonra kurguyla harmanlayarak ve edebi ifadelerle yeniden yazarak yeni bir metin oluşturmaktadır (Obermüller 2008: 4).

Schwarzenbach'ın Türkiye ve Türkler konusunda eleştirel ifadelerle aktarımı, yukarıda verilenlere sınırlı değildir. Günlüğün devamında da yine görülmektedir. Çalışmanın sınırlı olması nedeniyle tümü ele alınamamıştır.

\section{Sonuç}

Annemarie Schwarzenbach, dönemi için sıra dışı bir yazar ve gazeteci resmi çizmektedir. 23 yaşında doktorasını tamamlamış, hemen ardından Berlin'e, oradan da nasyonal sosyalizmin baskısı nedeniyle gazetecilik göreviyle Irak'a kadar süren bir doğu yolculuğu gerçekleştirmiştir. Türkiye'ye gidişi de bu yolculuk kapsamındadır. Ancak, nasyonal sosyalizmden kendisi gibi kaçmak zorunda kalmış kişilerin yerleşme imkânı bulduğu Türkiye konusundaki değerlendirmeleri birçok noktada olumsuzdur. Alman Göçmenlerin, üniversite reformu kapsamında gelişlerinin organize edildiği en hareketli dönemde Türkiye'ye gelmiştir. Çalışmalar Zürih merkezli, Schwarzenbach'ın da bulunduğu çevrede yürütülmüştür. Alman bilim insanlarının Türkiye’ye gitme ihtimali ortaya çıktığında, Türkiye hemen harekete geçmiştir. Söz konusu göçmenlerin Türkiye'ye gidişi konusunda özverili ve hızlı çalışılmıştır. Fakat, Schwarzenbach'ın seyahat notlarında Türkiye'yi Alman Göçmenler bağlamında olumsuz bir bakış açısıyla resmettiği görülmektedir.

Aynı yaklaşımı, Türkiye'nin o dönem yürütmekte olduğu reform hareketini yorumlama şeklinde de görülmektedir. Reformları sık sık çılgınlık, boş hayal, abartılı, anlamsız manalarına geldiği şeklinde değerlendirdiği görülmektedir. Yürütülen çalışmaları ve projeleri aceleci, çok yoğun, gerçeklikten uzak bulduğuna dair açık ifadeleri de mevcuttur. Öte yandan, göçmen Almanlardan sadece Türkiye'deki önemlerinden ve ileriye dönük kaygılarından yola çıkarak bahsetmiştir. Yabancıların 
ülkede zorluk yaşaması çok doğal olmakla beraber, elbette ki söz etmeye de değerdir. Ancak Schwarzenbach, konuyu sadece olumsuz açıdan ele almış, söz konusu kişilere Türkiye'nin fayda ve katkısına hiç değinmemiştir.

3 Aralık 1933 tarihinde Neue Zürcher Zeitung adlı gazetede, İstanbul Üniversitesi reformu hakkında haberi yayınlanmasına ve aynı sırada kendisi de Türkiye'de olmasına rağmen, bu konuya dair seyahat günlüğünde hiçbir bilgi veya fikir dile getirmemiş̧tir. Bu bağlamda, ayrı bir çalışmada, eş zamanlı olarak kaleme almış olduğu haber metinlerinde Türkiye imgesi ve yazarın gazeteci kimliğiyle Türkiye'ye yaklaşımı ele alınabilir.

Schwarzenbach, seyahat günlügünde, Türkiye'nin yeni kurulmuş bir cumhuriyet olarak duyduğu heyecanı, baskıcılıkla eş tutmaktadır. $\mathrm{Bu}$ sonuca, Avrupa'da deneyimlediği kitle hareketlerinden yola çıkarak vardığı muhtemeldir. Öte yandan, Schwarzenbach'ın 1990'lı yılların başında feminist akımın kült isimlerinden biri olduğu göz ardı edilmemelidir. Türkiye'nin Cumhuriyet dönemindeki hılı ve yoğun uygulamaları, Schwarzenbach'ın gözünde “erkek egemen, baskın olan bakış açısı ve yaklaşım" olarak da değerlendirilmiş görünmektedir. Ancak, bu noktada, Türk yetkilileri alenen "cahil" olarak tasvir etmesinin, feminist bir yaklaşımla açıklanamayacağı da ortadadır.

Schwarzenbach'ın, seyahati boyunca Türk yetkililerce de tanındığı, saygıyla karşılandığı, kendisinin eleştirel anlatımlarının arasında dahi görülmektedir. Fakat Schwarzenbach, kendisine gösterilen ihtimamın da, Alman mimar ve mühendislerin Türkiye'deki eserleri ve projelerinin de, onca göçmenin Türkiye'ye yerleşerek mesleğine ve yaşamına, oldukça iyi şartlarda olmak üzere, devam etmesinin de aynı Cumhuriyet düzenlemeleri ve reformistlerin çalışmaları sonucunda mümkün olduğunu unutmuş veya aktarmak istememiştir. Çalışmada sunulan örnekler ve metnin geri kalanına da bakıldığında, Schwarzenbach'ın Türkiye'yi ve Türkleri tanıtırken, öncesinde edindiği, fakat kaynağına dair bilgi vermediği çok önemli iddiaları kesin bir dille sunduğu ve Türkiye'yi bu bilgilere göre yorumladığı görülmüştür. Bunun sonucunda ise seyahat günlüğünde ortaya koyduğu Cumhuriyet Dönemi Türk ve Türkiye imgesinin olumsuz olduğu görülmektedir.

\section{Kaynakça}

Decock, Sofie (2012): Die Suche nach bergenden Räumen als Reise und Schreibprogramm.Annemarie Schwarzenbachs journalistische Afrika-Texte. In: Orbis Litterarum 67:1. 1-24.

Dieterle, Regina (1992): Annemarie Schwarzenbach (1908-1942). Zeugin Ihrer Zeit. Die Wiederentdeckung einer sozialkritischen Reporterin. In: Zeitschrift für Geschlechterforschung und visuelle Kultur, Nr.14.67-73.

Heinrichs, Petra (2010): "Unser Leben gleicht einer Reise“: Türkei-Bilder in den Texten Annemarie Schwarzenbachs. In: Globalisierte Germanistik: Sprache-Literatur-Kultur Tagungsbeiträge İzmir. 114-125.

Huszár, Ágnes (2009): Die Frau im Spiegel des goldenen Auges: Annemarie Schwarzenbach. In: Grenz/über/schreitungen, Publicationes Universitatis Miskolciensis. Sectio Philosophica tom. 14 fasc. 3. 249-256. 
Kellermann, Katharina (2017): Heroinen der Technik zwischen 1918 und 1945. Selbstinszenierung Funktionalisierung - Einschreibung ins deutsche kulturelle Gedächtnis. In: Bamberger Studien zu Literatur, Kultur und Medien. Hg. von Andreas Bartl, Hans-Peter Ecker u.a., Band 19. Bamberg: University of Bamberg Press.

Schmidt, Kira (2011): Tendenzen der Annemarie Schwarzenbach-Forschung (2005-2010). In: Zeitschrift für Germanistik, Neue Folge, Vol. 21, No. 3. 604-610.

Linsmayer, Charles (2011): Killy Literaturlexikon. Autoren und Werke des deutschsprachigen Kulturraumes 2., vollständig überarbeitete Auflage. Band 10, Ros-Se. Hg. Wilhelm Kühlmann u.a.,Berlin/Boston: de Gruyter

Obermüller, Klara: Am Ende aller Wege Festvortrag zum 100. Geburtstag von Annemarie Schwarzenbach, Schweizerische Nationalbibliothek, Bern 2008, https://docplayer.org/44277969Am-ende-aller-wege-festvortrag-zum-100-geburtstag-von-annemarie-schwarzenbach.html (son erişim: 27.04.2020)

Samsami, Behrang (2011): Die Entzauberung des Ostens. Zur Wahrnehmung und Darstellung des Orients bei Hermann Hesse, Armin T. Wegner und Annemarie Schwarzenbach. Bielefeld: Aisthesis Verlag

Schwarzenbach, Annemarie (2002): Winter in Vorderasien. Tagebuch einer Reise. Basel: Lenos Verlag.

Photographs by $\quad$ Annemarie $\quad$ Schwarzenbach $\quad-\quad$ Turkey. https://commons.wikimedia.org/wiki/Category:Photographs_by_Annemarie_Schwarzenbach__Turkey?uselang=de (Son erişim 20.04.2020) 